\title{
The Implications of Poverty on the Cameroon Economic Emergence Vision 2035
}

\author{
Saidou Baba Oumar ${ }^{1,2}$, Molem Christopher Sama ${ }^{2}$ \\ ${ }^{1}$ Department of Economics, The University of Bamenda, Bambili, Cameroon \\ ${ }^{2}$ Department of Economics and Management, University of Buea, Buea, Cameroon \\ Correspondence: Saidou Baba Oumar, Department of Economics, The University of Bamenda, Bambili, Cameroon.
}

Received: July 26, 2016

doi:10.11114/aef.v4i3.2335
Available online: April 5, 2017

URL: https://doi.org/10.11114/aef.v4i3.2335

\begin{abstract}
This paper examines the implications of poverty on the Cameroon economic emergence vision 2035. Both primary and secondary data were collected on selected indicators of economic emergence for the period 1990-2035 and analyzed with descriptive and inferential tools of data analysis. The results reveal that the performance of major socio-economic indicators of well-being is poor in Cameroon. In consonance with the situation, a global assessment of the economic performance of Cameroon shows little hope for the economic emergence of the country by the target date of 2035. In order for the goal of economic emergence of Cameroon to come true as planned, it is suggested that the problem of poverty should be solved first by appropriately targeting macro-economic variables through policies that focus on job creation, provision of basic needs and services of life to people.
\end{abstract}

Keywords: development, inequality, needs, services, people, Cameroon

\section{Introduction}

Poverty is a common, complex, and invasive world phenomenon. Generally, it refers to a socio-economic condition of a person or country facing lack of adequate access to basic survival needs. Wherever there is poverty, one observes negative effects on the physical and mental living conditions of people. From every angle, those who suffer from poverty cannot afford easy access to basic needs of life and services such as food, shelter, clothing, potable water, healthcare, electricity, education, decent jobs, and sanitation. Today, many people around the globe are compelled to sleep hungry, live under bridges or in precarious settlements, dress wretchedly, die of curable diseases, and drink untreated water from rivers or wells, light households with bush lamps, and drop out of school before completing primary education. Forgha (2006) observes that the striking features of poverty in Africa comprise low dietary intakes, low levels of education, low spending on public goods, low life expectancy at birth, high marginal propensity to consume, and high rates of infant mortality. Ali et al. (2002) reveal that $75 \%$ of the population in rural Africa lives in poverty, whereas in urban centers poverty accounts for about $55 \%$ of the population. The same source argues that the lower degree of urban poverty compared to rural poverty stems from the relatively high access of city residents to social amenities such as education, healthcare, potable water, electricity, shelter, and sanitation. On the average $65 \%$ of the population in Africa lives in poverty, thus making the phenomenon a big challenge to the continent.

In an attempt to fight against poverty, African countries have embarked on a series of development programs to ensure a long run sustainable provision of financial assistance, infrastructure, mass education (van Edig, 2005) and job opportunities to their populations. In Cameroon for instance, poverty affects more than $33.30 \%$ of the population (National Institute of Statistics [NIS], 2007). The rate of poverty in the country engenders high rates of unemployment and underemployment, high rates of rural-urban migration, prevalence of diseases such as malaria and typhoid, and crime (Amin, 2001). Therefore due to the severity of economic hardship on the population, the government of Cameroon (GoC) initiated some policy reforms to address the poverty situation in the country. In 1996, GoC increased its spending on the provision of social services to 20.6 million Franc de la Communauté Financière de l'Afrique (FCFA) or $\$ 412$ thousand (1FCFA equivalent to $\$ 0.02$ as at 29 October 2015), while in 2001, it earmarked 111.8 million FCFA (\$2236 thousand) to eradicate poverty in rural areas (Epo \& Baye, 2007). Moreover, GoC launched the Structural Adjustment and Economic Stabilization Program (SAESP) in 1987 to liberalize the exchange rate, prices, and trade and restructure or liquidate some public enterprises with the view to contain the crisis and revive the economy without 
borrowing or seeking assistance from foreign financial bodies (Baye, 2004). Also, it attempted to empower women through the Projet de Reduction de la Pauvreté et Actions en Faveur des Femmes dans la Province de L'Extrême-Nord (PREPAFEN) program between 1999 and 2009 by conceding 900 million FCFA or $\$ 18$ million in the then Extrême-Nord (EN) Province, now EN Region (African Development Bank [AfDB], 2011). Besides, GoC produced the National Employment Policy Paper (NEPP) alongside the Employment Program for Youths, Women and Disadvantaged Groups (EPYWDG) to finance 866 projects that offered job opportunities to 6.5 thousand people who were placed under the National Employment Fund (NEF) in 2006 (International Monetary Fund [IMF], 2008). As a result, governments and international organizations such as the World Bank (WB) and IMF now admit that for any adjustment program to succeed, it has to take into account the needs of the poor (WB, 1996).

Although one of the objectives of economic development is the substantial reduction of poverty rate, the economic reforms introduced in Cameroon to achieve the aim have yielded unsatisfactory results because poverty is still rife and glaring in the country, especially in remote areas where people cannot afford the essential needs of clothing, food, shelter (NIS, 2007), decent job, education, healthcare, potable water, and sanitation. In 2006, this socio-economic condition pushed WB and IMF to admit the country into the category of Highly Indebted Poor Country (HIPC) where the Millennium Development Goal (MDG) of halving the1990's level of extreme poverty by December 2015 was unlikely to be met. To sum up, the efforts deployed by $\mathrm{GoC}$ to redress the economic state of the country through a series of policy measures produced adverse effects, ranging from the retrenchment of workers, freezing of staff advancement, downward review of civil servants' salaries and government's withdrawal from the social sector of the economy (Baye, 2004) to an embargo on recruitment into public service. These awful upshots bear direct link to the fact that most of the programs and projects designed to eradicate poverty in the country failed due to poor implementation or misplacement of priorities by targeting the wrong population.

At this juncture therefore, it is crucial to appraise the poverty situation in Cameroon and its implications on the realization of the economic emergence vision 2035 for the country. Specifically, the paper envisages to:

- Understand the pattern of poverty in Cameroon,

- Explore the causes and remedies of poverty in Cameroon,

- Determine the viability of the economic emergence deadline dream for Cameroon, and

- Draw lessons for the economic emergence of the country by 2035.

The remaining part of the paper is structured as follows. Section 2 explores the review of literature, followed by an explanation of the methodology used in analyzing collected data in Section 3. Section 4 presents results and discussion of findings, while Section 5 draws the conclusion and lessons from the paper.

\section{Literature Review}

Several theories attempt to explain the poverty phenomenon and its ramifications in the society. The literature on the phenomenon is mainly dominated by two streams - the cultural theories of poverty (CTsP), and structural theories of poverty (STsP). On one hand, the cultural theories of poverty attribute poverty to the characteristics embedded in the poor themselves through their pattern of behavior, attitude and judgment which prevent them from evolving in the social context. On the other hand, the structural theories of poverty tie the state of poverty to the conditions of lack of or limited access to education, health, decent jobs, proper shelter and sanitation, quality food and water, decent clothing, and regular energy supply under which the poor live and consider these conditions as adaptations or responses of the poor to the hostile arrangements of the society they are suffering from. The sub-culture theory of poverty (SCTP), individual attributes theory of poverty (IATP) capture the arguments of CTsP. The personal income distribution and alleviation theory of poverty (PIATP) or marginal productivity theory of poverty alleviation (MPTPA), natural circumstantial theory of poverty (NCTP), power theory of poverty (PTP), structure theory of poverty (STP), trickle down theory of poverty (TTP), and vicious circle theory of poverty (VCTP) account for STsP.

SCTP epitomizes an economic scenario of high rate of unemployment and underemployment, low wages, money economy, and people with low skills as factors that lead to the growth of the culture of the poor. It holds that both the poor and the rich have a pattern of values, beliefs, and behavioral norms they learn in connection with their status which are socially generated but individually transmitted from generation to generation (Lewis, 1959), thus making the poor victims of the dysfunction of their culture for poverty begets poverty (Blank, 2010). Under such arrangements, the poor realize that they have a marginal position within a highly stratified and individualistic society which does not offer them any hope for self-actualization, and accept negative and deviant behaviors such as out of wedlock birth, welfare dependence, and crime (Wilson, 1996; Rankin \& Quane, 2000). Consequently, the poor develop a common set of values, norms and patterns of behavior which are different from the dominant culture and its institutions because they do not serve them (Lewis, 1959) and out of hopelessness of having low expectation on what can be achieved in life (Jung \& Smith, 2007), the sub-culture of poverty persists and expands in the society. 
IATP holds that the poor are answerable to their own predicament because an individual who has the ability, motivation and aptitude to perform some activities in the society can easily breakthrough and attain self-actualization on the ladder of income and wealth in the society (Gans, 1995). Some authors substantiate this point by mentioning the phenomenon of social Darwinism which holds that based on the ideas of natural selection and biological predisposition of human beings, the poor are poor because their poverty status is naturally ordained (Weber, 2001; James, 2006) and guided by destiny. Thus, those who do not succeed in life must blame themselves (Bradshaw, 2006). Although talents are determinant in shaping the future position of people in the society, the reality shows that there are other external forces beyond the control of the individual that influence this positioning in the society. In developing countries for instance, these forces are linked to political affiliation, tribalism, nepotism, market imperfections, poor government policies, ethnic clashes, bad governance, and immorality.

NCTP recognizes geographical locations (Dwyer, 2010; Lichter et al., 2011), unforeseen natural disasters, physically and mental disabilities, old age, and unemployment, lack of or mismanagement of resources needed to generate well-being and income (Weber \& Jensen, 2004) or lack of power to claim redistribution of resources as factors responsible for the presence of poverty in some places of the world (Morrill \& Wohlenberg, 1971). Similarly, it is widely accepted that economic growth achieved with an unsustainable rate of natural resources exploitation or production of harmful by-products can indirectly have detrimental effects on the poor via its negative impact on the natural environment (Davis \& Sanchez-Martinez, 2014). Dasgupta et al. (2005) mention that the health damage suffered by poor households that are directly exposed to water, land, air pollution or climate change, or other environmental disasters in less industrialized countries (LICs) and most industrialized countries (MICs) contributes to erode the human capital stock of poor individuals, thereby making them more likely to gain poor levels of income. In most developing countries this form of poverty finds its essence in the absence of or poor planning and in inertia. Reinstadler and Ray (2010) conclude that health and age are major ingredients of people's stock of human capital in the sense that they indirectly influence the likelihood of the incidence of poverty as a poor health condition implies a lower likelihood of being able to work as poor skills do, hence a higher probability of ending up poor.

PIATP or MPTPA addresses the micro-economic foundation of income inequality which translates into poverty. This theory focuses attention on the labor market and sees the demand and supply for labor as the main determinants of labor income in the classical system. It considers productivity as the driving force for poverty reduction in any economy (Mustapha et al., 2015; Fisher et al., 2016). According to the theory, the contribution which a worker makes to the revenue of the firm is equal to the additional output resulting from the employment of an extra worker multiplied by the price for which the firm sells a unit of its product. Besides, the theory explains that market imperfections guided by externalities, moral hazard, adverse selection, and incomplete information (Davis, 2007) and uncertainty due to the vulnerability of the poor to recessions, sickness or family breakdown, skepticism about government role toward policies addressing market failures contribute to the aggravation of poverty in the society (Banerjee \& Duflo, 2011). Consequently, a positive relationship between unemployment and poverty as well as between inflation and poverty rate can be predicted. For instance if the poor experience continuous unemployment, short employment periods throughout their lifetime, enroll in jobs but fail to retain them at all costs, they will likely return to poverty because the amount of accumulated savings at their disposal could hardly suffice to satisfy their survival needs. Similarly, inflation can depress workers' real income and generate poverty especially when the nominal income stagnates or grows at lower rates than prices do (Davis \& Sanchez-Martinez, 2014). Therefore, the steadiness of employment and general prices is central in preventing the persistence of poverty since the two can enable people to envisage better career prospects with higher expected future incomes (Ulimwengu, 2008) and influence the ability to transform assets into entitlements (Sen, 1999).

PTP is central in clarifying poverty conditions in LICs, particularly in Africa because it situates poverty in the dome of the political authority of the economy. The theory explains a situation where the ruling class expresses exploitative tendencies through which it determines economic models and organizes opportunities, income and wealth using the apparatus of the state power to act in their own selfish interest thereby enabling wealth and decision making to be concentrated in the hands of a few while the majority of the people lingers in poverty (Mead, 1993). Thus until conscience awakening of the poor masses in the fashions of the "IBB must go" of 1989 against Ibrahim Badamasi Babangida's administration after 8 years of military rule (1985-1993), "No" to the Olusegun Obasanjo 2007 run for a 3rd term of office (1976-1979 and 1999-2007) in Nigeria, 2011 "y en a marre" popular rise against Abdoulaye Wade's persistent amendments of the constitution of the Republic of Senegal to facilitate his running for a 3rd term of office in 2012 (2002- 2012) in Senegal, October 2014 "Balai citoyen" against the life presidency will of Blaise Compaoré after 27 years (1987-2014) of reign in Burkina Faso, Arab masses uprising of 2011 against long term serving rulers in Tunisia, Libya, Egypt, Bahrain, and Yemen movements to resist exploitation and overthrow the power system of the few in favor of the majority overtakes the scene of events, the poor will continue to live in poverty.

STP focuses attention on the macro-economy and views poverty as an offspring of macro factors. It holds that it is the configuration of the socio-economic and political order of the society that causes inequality, and thus poverty (Rank, 
2004). According to the theory, the dominant model of capitalism is the main promoter of high levels of income inequality and widespread of poverty across the world. It is argued that the structure of the United States (US) economy ensures that millions of people are poor irrespective of whether they are skillful or hardworking (Beeghley, 2000; Stoll, 2008; Lee, 2011), thus putting in place a social exclusion model through the stratification of the society into middle and wealthy classes or social, economic and political entities which accounts for the causes of poverty among people in the society owing to the practice and experience of exploitation (Daves \& Moore, 1945; Bessie, 1995; Cancian \& Danziger, 2009). Consequently, the inequality that fuels poverty in the world is the result of an intentional construct of the society created and maintained by social institutions and policies based on socio-demographic characteristics such as gender and race (Fisher, 1992; Blau \& Kahn, 2000; Darling, 2002; Figart \& Power, 2002; Hurst, 2004; Alkire, 2007; Gould-Werth, 2014), family size and structure, residence and age, work disability (Grusky, 2001), single parent household, minority household, gender, economic deprivation, immigration status (Ducan et al., 1998; Dickens \& Mcknight, 2008/2009; Schiller, 2008), limited healthcare and promotion benefits, filthy jobs, and low wages (Quigley, 2003), life expectancy, risk of incarceration, infant mortality, and risk of homicide (Shaefer et al., 2016).

TTP argues that government expenditure is the driving force for any economic development plan. The theory considers that an increase in government expenditure on economic and social amenities such as the provision of infrastructure, storage and marketing facilities, educational training facilities, healthcare services, good governance and subsidizing the production of essential commodities would produce a multiplier effect in the economy to benefit everybody. All other things being equal, this multiplier effect will lead to increase in interest rates, stimulate savings and reduce money demand to hold as idle balance, thereby increasing investment based on the classical assumption that investment equals savings, contribute to fighting against poverty (Sachs, 2005), and triggers the required transformation for achieving sustainable growth and employment generation for all in the society (Dauda, 2016).

VCTP explains that the existence of a system of mutually reinforcing relationships is the sole determinant of underdevelopment in LICs. It examines the poverty phenomenon by postulating an interrelated chain of events - a poor person or country is poor because the person or the country is poor, and may remain poor, unless the person's or country's level of income increases significantly enough to pull the person or country in question out of the poverty trap. The theory considers individuals and their communities as being caught in a spiral of opportunities and problems in which problems dominate and close opportunities to create a cumulative set of problems that make any effective response nearly impossible (Bradshaw, 2000). Consequently, the cycle of poverty repeats itself at both individual and community levels by immersing people into a condition of lack of jobs and income which eventually leads to the deterioration of self-confidence, weak motivation, vulnerability to illness, inadequate medication, depression, hopelessness, and fatalism (Bradshaw, 2006). VCTP suggests that for the circle to break, real income has to increase considerably but observation has shown that this is not possible because of low capital which makes productivity low and so binds the person or economy to poverty. This theory therefore, considers low income as one of the obstacles to development as low income leads to low purchasing power and saving capacity, and eventually low capital formation and low capital which are all translated into low level of productivity which again leads to low income, and the cycle continues (Nurkse, 1953). Also, Meier and Baldwin (1957) view poverty in terms of capital deficiency provoked by market imperfections and maintain that the development of natural resources is a function of the quality of human resources. On this premise, it is argued that where there is the lack of skills and absence of a high level of technology, available natural resources will continue to remain idle, under-utilized and misused. With such a scenario, it becomes evident that the under-developed natural resources enhance people's levels of poverty both as a cause and as a consequence. In other words, the poorer the people are, the less developed will the natural resources be, and the lesser the development of natural resources is, the more economically backward will the people be, hence the continuity of the poverty cycle.

However in Cameroon, Forgha (2006) observes that the sub-culture of people contradicts SCTP in the sense that people in the country are voiceless and very docile even to verbal and incriminating instructions from hierarchy. This behavior is forced on them by a system of government where the head of state and top office holders are considered flawless and are almost worshipped by their subordinates. Under such system of administration, the proposals of IATP appear untenable because a person who is self-motivated, full of strength and vitality, and has high skills in the country might still remain poor if he or she condemns external forces such as tribalism, nepotism, corruption, and immorality. Furthermore, incidental events such as the Lake Nyos gas disaster of 1986, Mount Cameroon volcanic eruption of 1999, episodes of drought and flood disasters in Littoral, Nord, and EN regions where some emergency assistance was provided by the government to assist the affected people with basic survival need items (food, medication, and clothing) had often been misdirected because part of the items and facilities meant for the victims was diverted by the elites in charge of the distribution of such items to serve personal use, thus plummeting the victims into a more hopeless condition and poverty as described in NCTP. As a result, it is worth noting that in Cameroon the reality shows that the assumptions of PIAT or MPTPA suffer from a serious constraint because factors such as social status and economic 
policies play an important role in determining the equilibrium of the labor market as opposed to the market mechanisms of demand and supply for labor. Conversely, observation indicates that even though the structure of the economy of Cameroon is hybrid, blending the features of both capitalism and socialism, the rate of poverty remains soaring, thus contradicting the claim of STP that capitalism is the key source of high level of income inequality and widespread poverty in LICs.

Moreover, a careful observation of the political scene in LICs shows that attempts by the masses to peacefully overthrow the power clique in order to restore political power to the people have failed because the government in power always neutralizes such tendencies by using the machinery of the state to asphyxiate anti-governmental movements as evidenced in the following cases. First in Burundi, Pierre Nkurunziza was forcefully re-elected in September, 2015 for a 3rd term of office after a decade of reign (2005-2015) against the mass protest of people from April to August 2015 and from the start of the protest the country is plunged into turmoil with over 400 people killed (British Broadcasting Corporation [BBC] AFRIQUE, 2015). Second, Alexandre Grigoryevich Luchasenko (in power since 1994) was easily re-elected for a 5th term of office in Belarus in the face of a weak political opposition (Tyrkalov, 2015). Third, the regime of Paul Barthélemy Biya bi Mvondo in power since 1982 survived the social unrest actions of 1992 and 2008 hardship protests of people in Cameroon. The regime has run for 34 years with the constitution revised a number of times to keep the president in power for life (Kouagheu, 2015). Fourth, Denis Sassou Ngeusso succeeded in concocting a referendum on 25th October 2015 to modify the constitution of the Popular Republic of Congo to enable his stay in power after 26 years of reign in Congo against the mobilization of the masses in September, 2015 (Radio AFRICA No 1, 2016). Fifth, Paul Kagame (in power since 2000) manipulated the July 2015 referendum for the change of the constitution of Rwanda to pave the way for another 7 year term of office for him in 2017 in Rwanda after 16 years of reign (Leveille, 2015). Sixth, despite the popular disapproval of the change of the constitution to enable a 3rd term of office candidacy in 2016 after a decade of democratic reign, Joseph Kabila Kabange (in power since 2001) ignored the voice of the people of the Democratic Republic of Congo (DRC) and imposed his will of conserving power (Radio Okapi, 2016) as epitomized with the case of Félix Houphouët-Boigny (1960-1993) in Côte d'Ivoire, Mubutu Sese Seko Kuku Ngbenduwa Za Banga (1965-1997) in Zaire; now DRC, Omar Bongo Odimba (1967-2009) in Gabon (Senewebnews-Bitimrew, 2012), Idi Amin Dada (1971-1979) in Uganda (Mateso, 2016), Teodoro Obian Ngeuma Mbasogo in power since 1979 in Equatorial Guinea, José Eduardo dos Santos in power since 1979 in Angola, Robert Gabriel Mugabe in power since 1987 in Zimbabwe, Omar Ahmad Al- Bashir in power since 1989 in Sudan, Idriss Déby Itno in power since 1991 in Chad, Issayas Afeworki in power since 1993 in Eritrea, or Abdelaziz Bouteflika in power since 1999 in Algeria (Mulumbu, 2014), hence the justification of PTP.

Furthermore, Forgha (2006) holds that the arguments of VCTP are not tenable because no process of social aspiration occurs and reoccurs consistently without modification based on the following observations. For instance, most industrialized countries (MICs) were in the past poor. As a result, they are in a better position to explain to LICs how they broke the vicious circle of poverty. Also, although low incomes weaken the ability to save, it is not obvious that high incomes per head will definitely generate high levels of savings because in Cameroon wealthy people spend much of their resources on ceremonies, festivities, and foreign travels than they save. Finally, although TTP agrees that inflation can stimulate productivity in an agrarian economy such as Cameroon, it is a fact that galloping and hyper-inflation deter growth and development as Baye (1998) explains that the price hikes that resulted from the 50\% devaluation of FCFA in January 1994, and the two salary cuts of civil servants have created a type of poverty among the public sector workers in Cameroon that compels them to consume second-hand goods, and food of low nutritional value by conceding quality to quantity.

To sum up, Blank (1997) as cited in Bradshaw (2006) notes that no one theory has emerged to replace or nullify the others. Yet Sameti et al. (2012) underline that among all theories of poverty, STP with its emphasis on the social exclusion aspect of people in the share of societal resources best captures the phenomenon of poverty in the society because it examines the processes, forms, causes and effects of poverty in the society from both the individual and community levels.

\section{Methodology}

This part of the paper focuses on two components. First, it gives the scope and description of the study area. Second, it explains the methods of data collection and techniques of data analysis.

\subsection{Scope and Study Area}

The scope of analysis for the paper runs from 1990 to 2035. The following points motivated the choice of the period of analysis. The year 1990 is the base year against which the objectives of MDGs are set and poverty reduction is one of the goals. The year 2035 is the target year set by GoC for the country to achieve economic emergence, and most programs, schemes and projects (Poverty Reduction Strategy Paper [PRSP], Growth and Employment Strategy Paper [GESP], PREPAFEN, MDGs, NEF, Vision 2035) designed to address and consolidate the efforts of GoC toward the 
realization of the agenda of economic emergence for Cameroon were fashioned within this period of review.

Cameroon is located in Central Africa. It covers an area of 475650 square kilometers $\left(\mathrm{Km}^{2}\right)$ and is bordered on the South by the Popular Republic of Congo, Equatorial Guinea, and Gabon, on the East by Central African Republic (CAR), on the North by a tiny fraction of Lake Chad, on the Northeast by Chad, and on the West by the Federal Republic of Nigeria (NIS, 2006; p. 2). In 2015, the population of Cameroon was estimated at about 23.4 million inhabitants (World Population Review [WPR], 2015) in which 43\% were under 15 years old (Population Reference Bureau [PRB], 2014) and 3\% above 65 years old (Central Intelligence Agency [CIA], n.d).

Although English and French serve as official languages, more than 250 native languages are used for communication by people across (AfDB, 2010; p.13) the 10 administrative regions of the country (Cameroon Tribune, 2008; p.3). Given an annual population growth rate mean of $2.6 \%$ (Republic of Cameroon [RC], n.d; p.3), the population of Cameroon is projected to reach 36.82 million inhabitants by 2035 .

On the globe, Cameroon is situated between latitudes $2^{\mathrm{O}}$ and $13^{\mathrm{O}}$ North of the equator and longitudes $8^{\mathrm{O}}$ and $16^{\mathrm{O}}$ East of the Greenwich Meridian (Office Central de Promotion Exterieur [OCPE], 2007). The country is characterized by tropical rain forests in the South, mountainous highlands in the West, and semi-arid savannah in the North. It witnesses two seasons in the year -rainy and dry. The rainy season runs from July to October in the North and April toDecember in the South, while the dry season spans November to June in the North and January to March in the South. In addition, the country registers a rainfall mean of 1600 millimeters (mm) per year (NIS, 2006).

The primary sector of the Cameroon economy employs $53.30 \%$ of the active population; the secondary sector engages $12.60 \%$ of the active population, while the tertiary sector occupies $34 \%$ of the active population (Quandl, n. d). However, the contribution of these sectors to the gross domestic product (GDP) of the country which in 2014 stood at $\$ 32.549$ billion (WB, 2015) is $22.50 \%$ for the primary sector, $29.70 \%$ for the secondary sector, and $47.80 \%$ for the tertiary sector (Doffonsou \& Singh, 2014; p.3). Then, it is worth noting that some of the problems confronting the country include stagnant per capita income, unequal distribution of income, hostile business atmosphere compared to other African states, and poverty.

\subsection{Methods of Data Collection and Techniques of Data Analysis}

Data used to analyze the phenomenon under examination came from secondary and primary sources. The secondary data were obtained from NIS, WB, and United Nations (UN) reports. The primary data were collected using a structured interview guide and 1550 participants in all were interviewed across the three grand geographical regions of the country at the rate of 155 participants per administrative region on their views about the emergence or non-emergence of Cameroon by 2035 using a random sampling technique of data collection with the help of research assistants. The three grand geographical regions of the country are designed based on the similarities of the socio-cultural background of the majority of the peoples living in given areas and the geographical characteristics of the concerned areas. Thus, the three grand geographical regions formed from the 10 administrative regions of Cameroon are: Grand North (GN) consisting of Adamaoua (AD), Nord (NO), and Extrême-Nord (EN) administrative regions; Grand West (GW) comprising Littoral (LT), Northwest (NW), Ouest (OU), and Southwest (SW) administrative regions; and Grand South (GS) composed of Centre (CE), Est (ES), and Sud (SU) administrative regions. Consequently, 465 participants were considered for GN, 620 participants were interviewed for GW, and 465 participants were interviewed for GS to arrive at the total population of 1550 participants. Table 1 summarizes the discussion.

Table1. Sampling and sample elements

\begin{tabular}{|c|c|c|c|c|}
\hline $\begin{array}{l}\text { Geographical region } \\
\text { Economic status }\end{array}$ & Grand North & Grand West & Grand South & Total \\
\hline Emergence by 2035 & $228(49.03)$ & 292(47.09) & $247(53.11)$ & $767(49.48)$ \\
\hline Non-emergence by 2035 & $237(50.96)$ & $328(52.90)$ & $218(46.88)$ & $783(50.51)$ \\
\hline Total & $465(100)$ & $620(100)$ & $465(100)$ & $1550(100)$ \\
\hline
\end{tabular}

NB: Figures in brackets are percentages.

Descriptive and inferential techniques of data analysis were used to capture the objectives of the investigation. The descriptive technique inspired the use of tables and percentages, while the inferential method informed the use of the Pearson Chi-square statistic $\left(\chi_{c}^{2}\right)$ to test for equality of proportions of samples given a set of hypotheses at $10 \%$ level of tolerance. The categorical random variables involved in the test were the types of economic statuses and geographical regions.

To accomplish the objectives of the inquiry, data related to each specific objective were drawn from different primary and secondary sources and updated accordingly using simple arithmetic computation or predicting future values of selected socio-economic indicators of well-being for the years under consideration based on minimum acceptable 
thresholds of progress or well-being of at least $70 \%$ achievement for the selected indicators. The difference between the levels of actual achievement with respect to basic needs of life or life span in the various years were then compared with the minimum acceptable thresholds to highlight the degree of deviations and establish when the selected indicators would signal hope toward the accomplishment of the economic emergence goal for Cameroon.

\section{Analysis and Discussion}

This part of the paper addresses the specific objectives of the paper. These are captured under separate sub-headings as follows.

\subsection{Pattern of Poverty in Cameroon}

Table 2 displays the poverty profile of Cameroon for the period 1990-2035. It shows an alternating pattern of increase and decrease in poverty rate in the country. In 1990 for example, the rate of poverty is about $51 \%$ and five years later it increases by 14 percentage points to reach $65 \%$, after which an average decline of 12 percentage points is observed for the period 2000-2005. The year 2010 shows an increase of 11.45 percentage points in the rate of poverty attaining $51.45 \%$. However, for the period 2015-2020, an average decline of 3.13 percentage points in the rate of poverty is anticipated after which a rise of approximately 3 percentage points may be experienced in 2025 from the $45.19 \%$ rate in poverty in 2020 followed by slight decreases of 0.38 and 0.75 percentage points for 2030 and 2035 , respectively. The rise and fall tendency of poverty rate in Cameroon can be explained by the lack of will and commitment of political leaders to enact a comprehensive poverty reduction package that offers a sustainable long-term support for the masses to overcome financial, material and psychological misery. Also, most poverty reduction programs are initiated to address short-term and emergency cases to back-up political campaign motives in order to win the electorate votes, and immediately after the pool results the programs become obsolete or short-lived to await revival only at the eve of another round of political campaign for leadership. This disposition converges with the arguments advanced by PTP, which hang up the perpetual state of people's poverty on the political elite of the society.

Table 2. Poverty profile for Cameroon, 1990-2035

\begin{tabular}{lllllllllll}
\hline $\begin{array}{l}\text { Year } \\
\text { Indicator }\end{array}$ & 1990 & 1995 & 2000 & 2005 & 2010 & 2015 & 2020 & 2025 & 2030 & 2035 \\
\hline Poverty rate (\%) & 50.61 & 64.72 & 50.50 & 40.00 & 51.45 & 48.34 & 45.19 & 47.89 & 47.51 & 46.76 \\
Percentage gap & - & +14.11 & -14.22 & -10.50 & +11.45 & -3.11 & -3.15 & +2.70 & -0.38 & -0.75 \\
\hline
\end{tabular}

In order to expatiate on the progression of monetary poverty in Cameroon between 1990 and 2035, the minimum amount of annual expenditure adult equivalence required to satisfy the basic needs of a person in the country is considered based on the consumption-expenditure or food energy intake (FEI) method to estimate the monetary poverty line at the level of consumable goods by taking the cost of consumption of a given quantity of energy intake indispensable for subsistence per day. As a result, FEI level of 2900 calories was retained as the standard below which one is regarded as poor (Food and Agriculture Organization [FAO] et al., 2001). Accordingly, in the case of Cameroon, the total monetary value of a basket of 61 food items that are mostly consumed by people and cover about $80 \%$ of their food consumption was considered to arrive at the 2900 calories FEI level, which corresponds to a food monetary poverty line value per day adult equivalent (MPLVDAE) of 637 FCFA ( $\$ 12.74)$ or 232505 FCFA (637*365 days) or $\$ 4650$ annual consumption expenditure adult equivalent (ACEAE). Based on 2001 price levels of a basket of food items, MPLVDAE for 2007 stands at 738 FCFA (\$14.76) corresponding to 269370 FCFA (738*365 days) or \$5387.4 ACEAE (NIS, 2007). Thus for Cameroon, households with ACEAE below 269370 FCFA (\$5387.4) are classified as poor.

Table 3 takes into account the inflation rate over time and the 2007 ACEAE threshold of 269370 FCFA(\$5387.4) as a base to describe the progression of monetary poverty in Cameroon for the period 1990-2035. It shows that the intensity of monetary poverty is high in Cameroon since out of the period of 46 years, only 6 years (1990-1995) or $13.04 \%$ of the period register an ACEAE greater than or equal to the minimum level of monetary poverty of 269370 FCFA (\$538.4). The other 40 years spanning 1996 to 2035 or $86.95 \%$ of the review period record an ACEAE lesser than the benchmark measure of monetary poverty of 269370 FCFA $(\$ 538.4)$ for the country. The deviation between the 2007 ACEAE threshold of 269370 FCFA (\$5387.4) and actual ACEAE of years for the review period remains positive and averages $11.11 \%(66.66 \div 6=11.11)$ only for the first 6 years $(1990-1995)$. But for the rest of the review period an average ACEAE deficit of 32203.76 FCFA $(1288150.70 \div 40=32203.76)$ or $\$ 644.07$ is observed against the monetary poverty line for the country. The observed average ACEAE deficit of 32203.76 FCFA (\$644.07) corresponds to an annual average percentage deficit of $11.95 \%(478.17 \div 40=11.95)$ for the country.

Based on the 2015 population estimate of 23.4 million inhabitants for Cameroon by WPR (2015) and considering the average family size of 6 people for the country, 3.9 million (23.4 million $\div 6=3.9$ million) households need to be protected against monetary poverty in the country. This implies that in 2015 alone, at least an average additional ACEAE of 125.6 billion FCFA or $\$ 2.5$ billion ( $32203.76 * 3.9$ million $=125.6$ billion $* 0.02=2.5$ billion) is required 
to satisfy the essential needs of all households in the country. On these bases and in consideration of the projected population of 36.82 million inhabitants $(36.82$ million $\div 6=6136667)$ for Cameroon in 2035, not less than an average supplementary ACEAE of 197.6 billion FCFA or $\$ 3.95$ billion $(32203.76 * 6136667=197.6$ billion $* 0.02=3.95$ billion) is required to take care of the survival needs of all households in the country. As a result from 2016 to 2035 , an average supplementary ACEAE of 8.08 billion FCFA or $\$ 161.6$ million (125.6 billion +197.6 billion= 323.2 billion $\div$ $2=161.6$ billion $\div 20=8.08$ billion) is to be made available every year by GoC to households through employment and business opportunities and legally due social benefits in order to comply with the arguments of TTP, justify the claims of PIATP or MPTPA, challenge the operational framework of VCTP, and achieve the 2035 vision of economic emergence of Cameroon. Above all, the failure of the country to meet MDGs stems from the fact that since 1990 poverty alleviation policies put in place superficially took into account the needs of the poor.

Table 3. Progression of monetary poverty in Cameroon, 1990-2035

\begin{tabular}{lllllllllll}
\hline Year & 1990 & 1995 & 2000 & 2005 & 2010 & 2015 & 2020 & 2025 & 2030 & 2035 \\
\hline Inflationrate (\%) & 0.6 & 1.0 & 1.2 & 2.0 & 3.4 & 4.2 & 5.0 & 6.3 & 6.0 & 5.2 \\
MPLVDAE (FCFA) & 1230 & 738 & 746.856 & 752.76 & 217.06 & 175.71 & 147.6 & 117.14 & 123 & 141.92 \\
ACEAE (FCFA) & 448950 & 269370 & 272602.44 & 274757.4 & 79226.47 & 64135.71 & 53874 & 42757.14 & 44895 & 51801.92 \\
MTMMP (FCFA) & 269370 & 269370 & 269370 & 269370 & 269370 & 269370 & 269370 & 269370 & 269370 & 269370 \\
DMTMMP (FCFA) & +179580 & 0 & +3232.44 & +5367.4 & -190143.53 & -205234.23 & -215496 & -226612.86 & $-224475-217568.08$ \\
PDMTMMP (\%) & +66.66 & 0 & +1.20 & +1.99 & -70.58 & -76.19 & -80 & -84.12 & -83.33 & -80.76 \\
\hline
\end{tabular}

Source:*WB (2013b)

MPLVDAE: Monetary poverty line value per day adult equivalent (in FCFA)

ACEAE: Annual consumption expenditure adult equivalent (in FCFA)

MTMMP: Minimum threshold measure of monetary poverty (in FCFA)

DMTMMP: Deviation from minimum threshold measure of monetary poverty = ACEAE - MTMMP (in FCFA) PDMTMMP: Percentage of DMTMMP (\%)

There are great differences in the rate of poverty between the regions of Cameroon. Table 4 gives the dispersion of poverty rate across the 10 administrative regions of the country over the period of review. It shows that the average rate of poverty for the regions of the country oscillates between $28.87 \%$ and $50.57 \%$ although the gross average for the country stands at $47.07 \%$. Yet among these regions of the country, EN Region registers the highest average rate of poverty (50.57\%), followed by NO Region (48.38\%), AD Region (43.50\%), ES Region (43.06\%), NW Region (42.48\%), CE Region (41.30\%), SU Region (34.67\%), LT Region (32.38\%), SW Region (30.39\%), and OU Region (28.87\%). The highest (45\%) and lowest (36\%) rates of poverty for CE Region are observed in 2010 and in 2000, respectively. For ES Region, the highest rate of poverty (50\%) is recorded in 1990 and the lowest rate of poverty (35\%) registered in 2010. With reference to EN Region, the highest (66\%) and lowest rates of poverty (40\%) occur in 1990 and in 2010, correspondingly. With regard to LT Region, the highest rate of poverty (42\%) occurs in 2015 and the lowest rate of poverty (28\%) in 2005. In NO, NW, SU, SW, and OU regions of the country, the highest rates of poverty $(64 \%, 51 \%, 44 \%, 36 \%, 32 \%)$ are experienced in 1990, 1990, 2015, 2015, 1995 and the lowest rates of poverty $(38 \%$, $36 \%, 29 \%, 27 \%, 25 \%$ ) are witnessed in $2010,2010,1990,2010,2010$; accordingly. The discrepancy in poverty rates between the regions of the country is associated with and traceable to the culture and attitudes of the people toward work and the geographical constraints of the areas in which they live as explained in SCTP, IATP, and NCTP.

Table 4. Dispersion of poverty across the regions of Cameroon, 1990-2035

\begin{tabular}{|c|c|c|c|c|c|c|c|c|c|c|c|}
\hline \multicolumn{12}{|c|}{ Region rate of poverty ( $\%$ ) } \\
\hline & 1990 & 1995 & 2000 & 2005 & 2010 & 2015 & 2020 ** & $2025^{* *}$ & $2030 * *$ & $2035^{* *}$ & Average percentage (\%) \\
\hline $\mathrm{AD}$ & 53 & 38 & 34 & 45 & 47 & 49 & 44.33 & 42.88 & 43.70 & 38.03 & 43.50 \\
\hline $\mathrm{CE}$ & 41 & 40 & 36 & 42 & 45 & 43 & 41.16 & 41.19 & 41.39 & 42.29 & 41.30 \\
\hline EN & 66 & 64 & 51 & 44 & 40 & 46 & 51.83 & 49.47 & 47.05 & 46.40 & 50.57 \\
\hline $\mathrm{ES}$ & 50 & 49 & 46 & 43 & 35 & 39 & 43.66 & 42.61 & 41.54 & 40.80 & 43.06 \\
\hline LT & 31 & 29 & 30 & 28 & 33 & 42 & 32.16 & 32.36 & 32.92 & 33.41 & 32.38 \\
\hline NO & 64 & 62 & 50 & 41 & 38 & 43 & 49.67 & 47.30 & 44.83 & 43.97 & 48.38 \\
\hline NW & 51 & 49 & 44 & 37 & 36 & 42 & 43.17 & 41.86 & 40.67 & 40.12 & 42.48 \\
\hline $\mathrm{OU}$ & 29 & 32 & 30 & 28 & 25 & 30 & 29.00 & 29.00 & 28.50 & 28.25 & 28.87 \\
\hline SU & 29 & 33 & 36 & 32 & 32 & 44 & 34.33 & 35.22 & 35.60 & 35.52 & 34.67 \\
\hline SW & 27.50 & 30 & 32 & 29 & 27 & 36 & 30.25 & 30.71 & 30.83 & 30.63 & 30.39 \\
\hline Cameroon & 51 & 65 & 50.5 & 40 & 38 & 43 & 47.92 & 47.40 & 44.47 & 43.46 & 47.07 \\
\hline
\end{tabular}

** Rate computed using 6 periods of 5 years moving average starting from 1990

\subsection{Causes and Remedies of Poverty in Cameroon}

Poverty is a recurrent problem in Cameroon. It is multifaceted and caused by intertwined factors. As a result, a remedy for it necessitates a holistic approach. Table 5 gives an inventory of some causes of poverty and possible solutions to it 
in the country. It indicates that in Cameroon, poverty emanates mainly from the nature of the economy, actions and reactions of the government and attitudes of the people in the country. These three main causes of poverty bear unprecedented consequences on the economy of the country. For instance with reference to the construct of the economy, the highly centralized system of administration contributes to delay in decision making on issues affecting the welfare of peripheral spheres to the central power. Against this background, the power of decision becomes concentrated in the hands of a few or elites who organize the system in their favor by putting in place wrong policies that limit the access of the masses to employment opportunities as explained by PTP, thereby exposing them to economic insecurity to the extent of becoming vulnerable to common diseases and casual natural disasters that NCTP explains better. Then, the situation contributes to a reduction in life expectancy at birth, drop in productivity at work, and amplifies mortality rates of their children in accordance with the arguments of PIATP. As a consequence beside the condition of hopelessness, the poor develop negative attitudes and find excuses by holding foreigners responsiblefor their state of poverty when it becomes very difficult for them to gain jobs as IATP describes. In some cases, violent conflicts between local people and the foreigners occur and sometimes generate unrest and thus the deterioration of security. A reversal of the actions and reactions of the government as well as the adoption of positive attitudes and reconfiguration of the structure of the economy are elements of response to these causes of poverty in the country.

Table 5. Poverty roots and solutions

\begin{tabular}{|c|c|c|}
\hline Root & Manifestation & Solution \\
\hline $\begin{array}{l}\text { Wrong economic } \\
\text { policies }\end{array}$ & $\begin{array}{l}\text { Growth of informal sector economy, limited access to basic socio-economic } \\
\text { needs, poor planning and exclusion of stakeholders in planning process, delay } \\
\text { in human resource development, limited employment opportunities, fragile } \\
\text { economic security }\end{array}$ & $\begin{array}{l}\text { Enactment of appropriate } \\
\text { economic policies through } \\
\text { consultation } \\
\text { stakeholders }\end{array}$ \\
\hline $\begin{array}{l}\text { Poor health and } \\
\text { natural disasters }\end{array}$ & $\begin{array}{l}\text { People's vulnerability to infectious diseases, stigmatization and natural } \\
\text { calamities, low productivity, socio-economic inequalities }\end{array}$ & $\begin{array}{l}\text { Offer of affordable health } \\
\text { facilities and disaster } \\
\text { preventive measures }\end{array}$ \\
\hline $\begin{array}{l}\text { Attitudes } \\
\text { beliefs }\end{array}$ & $\begin{array}{l}\text { High family dependency ratio, fatality, moral decadence, violence increase, } \\
\text { laziness }\end{array}$ & $\begin{array}{l}\text { Sensitization and } \\
\text { educational programs for } \\
\text { attitudinal change }\end{array}$ \\
\hline Demography & Illegal migration, prolonged domestic unemployment, conflict and crime & $\begin{array}{l}\text { Regular control and } \\
\text { persuasion for tolerance of } \\
\text { others }\end{array}$ \\
\hline $\begin{array}{l}\text { System } \\
\text { administration }\end{array}$ & $\begin{array}{l}\text { Highly centralized system with executive power having control over both } \\
\text { legislative and judiciary armsof government, frustration of communities }\end{array}$ & $\begin{array}{l}\text { Effective decentralization } \\
\text { of system of administration }\end{array}$ \\
\hline
\end{tabular}

\subsection{Feasibility of the Economic Emergence Deadline of 2035 for Cameroon}

Given that economic emergence implies improvement in the quality of lives of individuals, the dream of transforming the present living conditions of people to a better situation depends on the ability of the country to guarantee greater access to essential needs and services of decent life such as potable water, adequate sanitation, electricity, shelter, education, nutrition, employment, and healthcare (life expectancy at birth as proxy). Table 6 presents the level of access to these major socio-economic needs and services to establish whether or not the levels achieved over the period of review are adequate enough to support any claims in favor of or against the argument of economic emergence of Cameroon. It shows that over the period of review, only 3 or $37.5 \%$ of the 8 selected major socio-economic indicators of well-being registered a rate of access of at least $70 \%$ as at 2015, the target year for the attainment of MDGs. The remaining 5 or $62.5 \%$ of the selected major socio-economic indicators of well-being achieved less than $70 \%$. The rate of access to sanitation can only reach $70 \%$ in 2030 . The rate of access of $70 \%$ for electricity, shelter, and employment can still not be achieved even in 2035. Also, the access to good healthcare cannot improve to warrant a life expectancy of 70 years for people in the country even in 2035. Given these estimates of deplorable levels of access of people to the basic needs of life in the country, a greater portion of the population shall be compelled to continue living in poverty in line with he arguments of VCTP. 
Table 6. Level of access to essential survival needs and services by people in Cameroon

\begin{tabular}{|c|c|c|c|c|c|c|c|c|c|c|}
\hline $\begin{array}{l}\text { Year } \quad \square \\
\text { Indicator }\end{array}$ & 1990 & 1995 & 2000 & 2005 & 2010 & 2015 & 2020 & 2025 & 2030 & 2035 \\
\hline $\begin{array}{l}\text { Potable water } \\
(\%)\end{array}$ & $49 \mathrm{c}$ & $56 f$ & $63 c$ & $70 f$ & $77 f$ & $84 f$ & $91 \mathrm{f}$ & $98 \mathrm{f}$ & $105 f$ & $112 \mathrm{f}$ \\
\hline Sanitation (\%) & $39 d$ & $43 g$ & $47 d$ & $51 \mathrm{~g}$ & $55 \mathrm{~g}$ & $59 \mathrm{~g}$ & $63 \mathrm{~g}$ & $67 \mathrm{~g}$ & $71 \mathrm{~g}$ & $75 \mathrm{~g}$ \\
\hline Electricity (\%) & $41 \mathrm{~h}$ & $43 \mathrm{~h}$ & $45 \mathrm{~h}$ & $47 \mathrm{~h}$ & $49 \mathrm{e}$ & $51 \mathrm{~h}$ & $53 \mathrm{~h}$ & $55 \mathrm{~h}$ & $57 \mathrm{~h}$ & $59 \mathrm{~h}$ \\
\hline Shelter (\%) & $49.20 \mathrm{j}$ & $50.40 \mathrm{j}$ & $51.60 \mathrm{j}$ & $52.60 \mathrm{j}$ & $52.10 \mathrm{k}$ & $52.35 \mathrm{k}$ & $52.22 \mathrm{k}$ & $52.28 \mathrm{k}$ & $52.25 \mathrm{k}$ & $52.26 \mathrm{k}$ \\
\hline Education (\%) & $68.77 n$ & $69.13 n$ & $68.41 \mathrm{~m}$ & $69.85 \mathrm{p}$ & $71.30 \mathrm{~m}$ & $70.57 x$ & $70.93 x$ & $70.75 x$ & $70.84 x$ & $70.79 x$ \\
\hline Nutrition (\%) & $62 q$ & $67.70 q$ & $76.90 q$ & $86.60 q$ & $90.90 q$ & $88.75 \mathrm{r}$ & $89.82 \mathrm{r}$ & $89.28 \mathrm{r}$ & $89.55 r$ & $89.41 \mathrm{r}$ \\
\hline Employment (\%) & $65.15 u$ & $65.80 \mathrm{~m}$ & $64.50 \mathrm{~m}$ & $66.09 \mathrm{~m}$ & $67 \mathrm{~m}$ & $66.54 \mathrm{t}$ & $66.77 \mathrm{t}$ & $66.65 t$ & $66.71 \mathrm{t}$ & $66.68 \mathrm{t}$ \\
\hline $\begin{array}{l}\text { Healthcare } \\
\text { (years) }\end{array}$ & $53.60 \mathrm{~m}$ & $53.22 \mathrm{~m}$ & $51.93 \mathrm{~m}$ & $51.89 \mathrm{~m}$ & $53.70 \mathrm{~m}$ & $52.79 w$ & $53.24 \mathrm{w}$ & $53.01 \mathrm{w}$ & $53.12 \mathrm{w}$ & 53.066 \\
\hline
\end{tabular}

Sources:

c :United Nations [UN] (2010a); d: UN (2010b); e: WB (2013a); m: WB (2016)

f: Authors -Calculation is based on assumed increase of 7 percentage points every 5 years drawing from 1990 and 2000 estimates of 14 percentage points difference of UN (2010a) divided by 2.

$\mathrm{g}$ : Authors-Calculation is based on assumed increase of 4 percentage points every 5 years from 1990 and 2000 estimates of 8 percentage points difference of UN (2010b) divided by 2 .

h: Authors-Calculation is based on assumed increase of 2 percentage points every 5 years drawing from 2002 and 2007 estimates of $46 \%$ and 48\% of LAUREA (n.d; p.12) on WB (2013a) estimate of $49 \%$ for 2010.

$\mathrm{j}$ : Authors - Calculation done by subtracting from $100 \%$ the rate of urban population living in slums provided by WB (2016)

k: Authors - Calculated as average for 2 consecutive preceding years rates on the row for Shelter based on WB (2016)

$\mathrm{n}$ : Authors - Calculated as average for 2 consecutive proceeding years rates on the row for Education based on WB (2016)

p: Authors - Calculated as average based on rates for 2000 and 2010 provided by WB (2016)

q: Authors - Calculation done by subtracting from 100\% the rate of undernourished population provided by WB (2016)

r: Authors - Calculated as average for 2 consecutive preceding years rates on the row for Nutrition based on WB (2016)

t: Authors - Calculated as average for 2 consecutive preceding years rates on the row for Employment based on WB (2016)

u: Authors - Calculated as average for 1995 and 2000 rates provided by WB (2016)

w: Authors - Calculated as average for 2 consecutive preceding years ages on the row for Healthcare based on WB (2016)

$\mathrm{x}$ : Authors - Calculated as average for 2 consecutive preceding years rates on the row for Education based on WB (2016)

To obtain the proportion of people expressing their views on the type of economic status Cameroon will assume by 2035, a simple percentage computational procedure is employed by taking the ratio of people who have subscribed to a given type of economic status $\left(\mathrm{n}_{\mathrm{i}}\right.$, where $\mathrm{i}$ : Type of economic status) over the total number of people for each grand geographical region $(\mathrm{NPGj}$, where $\mathrm{j}$ : GN, GW, GS). Based on this, the proportion $(\mathrm{Pj}$, ) of the population that believes in the economic emergence status of Cameroon by 2035 for the three grand geographical regions (GN, GW, and GS) can be obtained as follows.

PGN: Proportion of people believing in economic emergence of Cameroon by 2035 in GN $(228 \div 465=49.03 \%)$

PGW: Proportion of people believing ineconomic emergence of Cameroon by 2035 in GW $(292 \div 620=47.09 \%)$

PGS: Proportion of people believing ineconomic emergence of Cameroon by 2035 in GS $(247 \div 465=53.11 \%)$ 


\subsection{Hypothesis Testing}

In order to answer the question of whether or not Cameroon can attain the status of economic emergence by 2035, the null and alternative hypotheses for the test were formulated based on the views of respondents obtained from the populations of the three constituted grand geographical regions of the country. These hypotheses are stated as follows.

Null hypothesis- $\mathrm{H}_{0}$ :There is no difference among the three population proportions believing in the economic emergence of Cameroon by $2035\left(P_{G N}=P_{G W}=P G S\right)$.

$>$ Alternative hypothesis- $\mathrm{H}_{1}$ :At least one of the three population proportions believing in the economic emergence of Cameroon by 2035 is different $\left(P_{G N}=P_{G W} \neq P_{G S}\right.$ or $P_{G N} \neq P_{G W}=P_{G S}$ o $\left.r P_{G N} \neq P G W \neq P G S\right)$.

Table 7 gives the column percentages on the feelings of respondents about the economic status of Cameroon by the deadline of economic emergence in 2035 across the three grand geographical regions (GN, GW, and GS) of the country. It shows that on the average, only $49.48 \%$ of the population of Cameroon believes in the economic emergence of the country by the deadline of 2035 . In detail, it explains that $49 \%$ of the sample population is optimistic about the economic emergence of Cameroon by 2035 in GN; $47 \%$ of the respondents believe in the economic emergence of Cameroon by 2035 in GW, and 53\% of the sample foresees the economic emergence of the country by 2035 in GS. Based on these statistics and on the average, $50.51 \%$ of the population of Cameroon expresses pessimism about the emergence dream of the country in 2035. The relatively high proportion of $53 \%$ of the population with the conviction about the realization of the economic emergence dream in 2035 in GS can be justified by the influence of the on-going renovation and construction of heavy-weight economic developmental infrastructure such as roads and seaports in Kribi in SU Region, and hydroelectric plant project at Lom-Pangar in ES Region for the people in these geographical regions argue that economic infrastructure such as roads, seaports, or hydroelectric plants promote economic emergence. According to the people in GS, when these economic development projects are properly managed the benefits accruing thereof can trickle down and impact the life of all citizens in the country, thus sustaining the claims of TTP. The relatively low proportion of less than 50\% registered in both GN and GW geographical regions pointing to people's pessimism about the actualization of the economic emergence dream is explained by the level of bribery and corruption, insecurity, and inadequate access to basic needs of survival that suffocate the daily life of residents in these two regions who argue that there is no sector of economic activity exempted from corruption and only a few individuals enjoy adequate access to essential subsistence needs in the country. As a result of this deficiency in good governance institutions, the expected returns to generate from the economic infrastructure put in place to accelerate the economic emergence of the country and enhance the living conditions of the citizenry may end up serving the selfish interest and pockets of a few persons. According tothe people in GN and GW, when this occurs, the country instead of emerging economically may regress and fall into the trap of perpetual poverty as described by VCTP because the expected returns have not trickled down to the common man as supported by TTP.

Table 7. Column percentages on respondents' views on economic status type of Cameroon by 2035

\begin{tabular}{lllll}
\hline $\begin{array}{l}\text { Geographical region } \\
\text { Economic status }\end{array}$ & Grand North & Grand West & Grand South & Total \\
Emergence by 2035 & 49.03 & 47.09 & 53.11 & 49.48 \\
Non-emergence by 2035 & 50.96 & 52.90 & 46.88 & 50.51 \\
Total & 100 & 100 & 100 & 100 \\
\hline
\end{tabular}

Given that the percentage point difference in the proportion of respondents who believe in the economic emergence of Cameroon by 2035 across the three grand geographical regions is minimal and ranges between 2 and 6 percentage point (GN and GW: \pm 2 percentage points, GN and GS: \pm 4 percentage units, GW and GS: \pm 6 percentage points), it is necessary to subject the three sets of respondents'feelings to an objective evaluation technique before drawing any conclusion. To comply with this requirement, $\chi_{c}{ }^{2}$ isused totest for the statistical significance of the equality of the proportions of the three samples based on the views of respondents about the economic emergence of Cameroon by 2035.

To run $\chi_{\mathrm{c}}{ }^{2}$ test for the statistical significance of equality of proportions there is the need to confront the observed (actual) proportions of the three grand geographical regions with their corresponding expected (theoretical) proportions. Since proportions are relative estimates accordingly obtained from absolute estimates of the respective three sets of populations under study, their absolute frequencies can be used as well to compute $\chi_{c}{ }^{2}$. Consequently, the pivot or contingency table of observed frequencies on the economic status type of Cameroon in 2035 by geographical regions can be constructed and the corresponding pivot table of expected frequencies derived by applying the appropriate formulae.Then the two pivot tables can be put together in a single table to complete the computational procedure of $\chi_{\mathrm{c}}^{2}$ (See appendices). Equation (1) gives the formula for computing $\chi_{\mathrm{c}}{ }^{2}$. Equation (2) corresponds to the formula for determining the expected frequencies, while Equation (3) represents the formula for deciding the degree of freedom to use at a given level of significance. The level of significance chosen for the test is $\alpha=10 \%$. 
$f_{i}:$ Observed or actual frequency of category $i$

$$
\begin{gathered}
\chi_{c}^{2}=\frac{\sum\left(f o_{i}-f e_{i}\right)^{2}}{f e_{i}} \\
f e_{i}=\frac{\left(\sum_{r i}\right)\left(\sum_{c i}\right)}{N} \\
D d=(R-1)^{*}(C-1)
\end{gathered}
$$

$f e_{i}$ : Expected or theoretical frequency of category $i$

$\Sigma_{r i}$ : Summation of row $i$

$\Sigma_{c i}$ : Summation of column $i$

$N$ : Total number of observations

$D d$ : Degree of freedom

$R$ : Number of rows

$C$ : Number of columns

For a conclusion to be reached about the test, $\chi_{\mathrm{c}}{ }^{2}$ is compared with the critical Chi-square value $\chi_{\mathrm{t}}{ }^{2}$. As a result if $\chi_{\mathrm{c}}{ }^{2}$ is found to be greater than $\chi_{\mathrm{t}}{ }^{2}\left(\chi_{\mathrm{c}}{ }^{2}>\chi_{\mathrm{t}}{ }^{2}\right)$ at the chosen level of significance and computed $D d$, the null hypothesis is rejected. On the contrary, if $\chi_{\mathrm{c}}{ }^{2}$ is found to be less than or equal to $\chi_{\mathrm{t}}{ }^{2}\left(\chi_{\mathrm{c}}{ }^{2} \leq \chi_{\mathrm{t}}{ }^{2}\right)$ at the chosen level of significance and computed $D d$, the null hypothesis is accepted. Based on the requirements of (1) and (3), it follows from Table 8 that at $\alpha$ $=10 \%$ with $D d=(2-1) *(3-1)=(1) *(2)=2, \chi_{c}{ }^{2}=3.908$ and $\chi_{\mathrm{t}}{ }^{2}=4.605$. Thus, since $\chi_{\mathrm{c}}{ }^{2}$ is less than $\chi_{\mathrm{t}}{ }^{2}(3.908<4.605)$, the null hypothesis that there is no difference among the three population proportions that believe in the economic status type of Cameroon by 2035 is accepted, meaning that the observed discrepancy among the three population

\begin{tabular}{|c|c|}
\hline Item & Entry \\
\hline $\mathrm{H} 0$ & $\begin{array}{l}\text { No difference among the three population proportions' view on type of economic status of Cameroon } \\
\text { by } 2035\end{array}$ \\
\hline H1 & $\begin{array}{l}\text { Difference among the three population proportions' view on type of economic status of Cameroon by } \\
2035\end{array}$ \\
\hline Control variable (CVa) & Type of economic status \\
\hline Category for CVa & Economic emergence status, non-emergence economic status \\
\hline Decision variable (DVa) & Geographical region \\
\hline Category for DVa & Grand Nord, Grand West, Grand South \\
\hline Row for $\mathrm{CVa}$ & 2 \\
\hline Column for DVa & 3 \\
\hline Degree of freedom $(D d)$ & 1 \\
\hline Level of significance $(\alpha \%)$ & 10 \\
\hline Sample size & 1550 \\
\hline$X c^{2}$ & 3.908 \\
\hline $\mathrm{Xt}^{2}$ & 4.605 \\
\hline Decision rule & $\mathrm{Xc}^{2}<\mathrm{Xt}^{2}$ \\
\hline Decision & Accept $\mathrm{H}_{0}$ \\
\hline
\end{tabular}
proportions occurs as a result of luck or chance.

Table 8. Recap of Chi-square statistic test outcome

\section{Conclusion}

The paper set out to examine the poverty incidence in Cameroon between the years 1990-2035. It is observed that poverty exhibits an alternating pattern of rise and fall over the period of review in consonance with situational cases of backed up political campaign motives to win electorate votes. The intensity of the phenomenon spreads over 40 years covering about $87 \%$ of the 46 years of analysis that achieve an ACEAE lesser than the minimum threshold measure of monetary poverty of 269370 FCFA (\$538.4) in the country. Also, given the projected population of about 37 million people in 2035, and an average size of 6 people per household for the country, an average additional ACEAE of 8.08 billion FCFA ( $\$ 161.6$ million) is to be made available every year by GoC to households through employment, business opportunities and legally due social emoluments to enable them meet survival needs of feeding, drinking potable water, clothing, shelter, education, energy supply, and healthcare in the country. Furthermore, the distribution of poverty across the regions of the country is observed to be uneven with a level of about 22 percentage points difference between the highest and lowest rates. Besides, observations on major socio-economic indicators of well-being such as sanitation, 
electricity, shelter, sanitation, and healthcare show that their performance to 2015 is below $70 \%$ or 70 years old except potable water, education, and nutrition in the country. Based on the performance of the socio-economic indicators of well-being and the feelings expressed by people across the three grand geographical regions of the country, the Pearson Chi-square test results suggest that despite the perceived percentage point differences between the proportion of people who believe and do not believe in the economic emergence of Cameroon by 2035, there is no significant statistical difference among the population proportions considered at $10 \%$ level of significance. This implies that the observed discrepancy occurs as a result of mere luck or chance. Overall, less than $50 \%$ of the population in Cameroon is optimistic about the economic emergence of the country by 2035. In view of the above, it is obvious that Cameroon cannot emerge in 2035 given the poor performance of less than $70 \%$ rate of access to major socio-economic indicators of well-being of more than $60 \%$ of the indicators discussed in the paper.

A series of lessons can be drawn from the aforementioned observations. Firstly, the lack of will and commitment from political leaders to enact a comprehensive poverty reduction policy package for a long run sustainable support to the poor reinforces and perpetuates the ideals of PTP toward maintaining people in a situation of dependency and poverty. Secondly, the poverty situation of people in Cameroon is rooted in the construct of the economy, inertia from the government and people's resignation to fate and destiny as explained by PTP, NCTP, IATP, and PIATP. Thirdly, poverty alleviation policies so far drafted and implemented since 1990 in Cameroon are superficial and have not taken the needs of the poor into consideration. Fourthly, the little achievements registered on some socio-economic indicators of well-being are similar to the arguments of PIATP but are not strong enough to challenge VCTP operational framework to drive toward the realization of the 2035 dream of economic emergence of Cameroon. Fifthly, unless all socio-economic indicators of well-being achieve the requisite score of 14 on a scale of 20, the global impact on people may not be positive due to the downward pull effect of poor performing indicators against better performing ones, hence a contradiction of TTP. Sixthly, the relatively high and low percentage of the population that believes in the economic emergence of Cameroon in 2035 is influenced by the discriminatory actions of the government in the execution of developmental projects across the country thus reinforcing the claims of SCTP. Areas for further investigation on this topical issue of economic emergence may include such aspects as the accessibility of people to adequate means of transportation, information communication technology, freedom of speech, security, and ease of doing business in the country.

\section{References}

AfDB (2011). Evaluation retrospective de performance-Cameroun: PREPAFEN, Guinée: PAAEF. Abidjan, ABJ: AfBD. Retrieved 27 March 2016 from

http://www.afdb.org/fileadmin/uploads/afdb/Documents/Evaluation-Reports-_Shared-With-OPEV_/Noted'orientat ionREPPssociauxFinal.pdf

African Development Bank [AfDB] (2010). The AfDB and Cameroon 40 years of partnership. Abidjan, ABJ: AfBD. Retrieved 11 September 2013 from http://www.afdb.org/fileadmin/uploads/afdb/Documents/Publications/rapport $\% 20$

Ali, A. A. G., Mwabu, G.., \& Gesami, R. K. (2002). Poverty reduction in Africa: Challenges and policy options, African Economic Research Consortium (AERC) Special Paper 36, Nairobi, NRB: AERC. Retrieved 15 March 2016 from https://www.researchgate.net/publication/252598738_Poverty_reduction_in_Africa_Challenges_and_policy_optio ns

Alkire, S. (2007). Choosing dimensions: The capability approach and multidimensional. In N. Kakwani \& J. Silber (Eds). The many dimensions of poverty. 89-119, New York, NY: Palgrave Mcmillan. Retrieved 29 March 2016 from http://download.springer.com/static/pdf/813/bok\%253Q987-0-230-5924007.pdf

Amin, A. A. (2001). Rural poverty and agricultural development in Cameroon. Bordeaux, BRD/Paris, PRS: Université Montesquieu-BordeauxIV-United Nations Education, Science and Cultural Organization (UNESCO). Retrieved 15 March 2016 from http://ged.u-bordeaux4.fr.SBAMIN.pdf

Banerjee, A. V., \& Duflo, E. (2011). Poor economics: A radical rethinking of the way to fight global poverty. New York, NY: Public Affairs.

Baye, F. M. (1998). Inequality and the degree of poverty among the public sector workers in Cameroon. The Nigerian Journal of Economic and Social Studies, 40(3), 433-452.

Baye, F. M. (2004). Growth and redistribution effects of poverty changes in Cameroon: A sharply decomposition analysis. Forum Paper 2004 Lord Charles Hotel, Somerset West, South Africa, SA, Oct 13-15. Retrieved 28 March 2016 from http://www.tips.org.za/files/Growth_and_Redistribution_Baye.pdf

Beeghley, L. (2000). The structure of social stratification in the United States. New York, NY: Pearson Education Inc. 
Bessis, S. (1995). From social exclusion to social cohesion: Towards a policy agenda. The Roskilde Symposium, University of Roskilde, Denmark: DNK, March 2-4. Retrieved 15 March 2015 from http://www.unesco.org/most/besseng.

Blank, R. M. (1997). It takes a nation: A new agenda for fighting Poverty. Princeton, New Jersey, NJ: Princeton University Press.

Blank, R. M. (2010). Selecting among anti-poverty measures: Can an economist be both critical and caring? Review of Social Economy, 61, 447-467. https://doi.org/10.1080/0034676032000160949

Blau, F., \& Kahn, M. (2000). Gender differences in pay. The Journal of Economic Perspectives, 14(4), 75-99. https://doi.org/10.1257/jep.14.4.75

Bradshaw, T. K. (2000). Complex community development projects: Collaboration, comprehensive programs and community coalitions in complex society. Community Development Journal, 35(2), 133-145. https://doi.org/10.1093/cdj/35.2.133

Bradshaw, T. K. (2006). Theories of poverty and anti-poverty programs in community development. Rural Poverty Research Center (RPRC) Working Paper No. 06-05, USA: RPRC. Retrieved 15 March 2016 from http://www.rupi.org/Forms/WP06-05.pdf

British Broadcasting Corporation [BBC] AFRIQUE (2015). Qui est Pierre Nkurunziza? Retrieved 07 December 2016 from http://www.bbc.com/afrique/region/2015/07/150722_nkurunziza

Cameroon Tribune No.9224/5424 of Thursday13 November 2008.

Cancian, M., \& Danziger, S. (2009). Changing poverty and changing anti-poverty policies. National Poverty Center (NPC) Working Paper Series No. 09-06, Michigan: NPC. Retrieved 04 October 2016 from http://www.npc.umich.edu/publications/u/working_paper09-06.pdf

Central Intelligence Agency [CIA] (n.d). The world factbook. Retrieved 15 February 2016 from https://www.cia.gov/library/publications/the-world-factbook/geos/cm.html

Darling, R. (2002). Partnership models in human services: Sociological foundations and practices. New York, NY: Kluwer Academic/Plenum Publisher.

Dasgupta, S., Deichmann, U., Meisner, C., \& Wheeler, D. (2005). Where is the poverty-environment nexus? Evidence from Cambodia, Lao PDR and Vietnam, World Development, 33(4), 617-638. https://doi.org/10.1016/j.worlddev.2004.10.003

Dauda, R. S. (2016). Poverty and economic growth in Nigeria: Issues and policies. Journal of Poverty. Retrieved 04 October 2016 from http://www.afdb.org/fileadmin/uploads/afdb/Documents/Publications/AEO_2016_Report_Full_English.pdf

Daves, K., \& Moore, W. (1945). Some principles of stratification, American Sociological Review, 10(2), 242-249. https://doi.org/10.2307/2085643

Davis, E. P. (2007). A confrontation of economic and theological approaches to "ending poverty"in Africa. Working Paper, London, LND: London School of Theology and Brunel University. Retrieved 29 March 2016 from http://www.ephilipdavis.com/poverty.pdf

Davis, E. P., \& Sanchez-Martinez, M. (2014). A review of the economic theories of poverty. London, LND: National Institute of Economic and Social Research (NIESR).

Dickens, R., \& McKnight, A. (2008/2009). The changing pattern of earnings: Employees, migrants and low-paid families. United Kingdom: CentrePiece. Retrieved 28 March 2016 from http://www.cep.lse.ac.uk/pubs/download/cp272.pdf

Doffonsou, R., \& Singh, L. S. (2014). African economic outlook: Cameroon 2014. Abidjan, ABJ, Paris, PRS, New York, NY: African Development Bank, Organization for Economic Cooperation and Development, United Nations Development Program. Retrieved 15 February 2016 from http://www.africaneconomicoutlook.org/fileadmin/uploads/aeo/2014/PDF/CN_Long_EN/Cameroun_EN.pdf

Duncan, G., Yeung, J., Brooks-Gunn, J., \& Smith, J. (1998): How much does childhood poverty affect life chances of children? American Sociological Review, 6(3), 406-423. https://doi.org/10.2307/2657556

Dwyer, R. E. (2010). Poverty, prosperity, and place: The shape of class segregation in the age of extremes. Social Problems, 57, 114-137. https://doi.org/10.1525/sp.2010.57.1.114

Epo, B. N., \& Baye, F. M. (2007). Poverty reduction in Cameroon, 1991-2001: The role of growth and income 
redistribution. Retrieved 28 March 2016 from

file://C:/DOCUMENT 1/COLONE 1/LOCALS 1/Temp/MAMA_pdf-1.pdf

Figart, M., \& Power, M. (2002). Living wages, equal wage: Gender and labor market policies in the United States. New York, NY: Routledge.

Fisher, G. M. (1992). The development of the Orshansky's poverty thresholds and their subsequent history as the official U.S. poverty measure. Retrieved 29 March 2016 from

https://www.census.gov/hhes/povmeas/publications/orshansky.html

Fisher, J., Johnson, D., Latner, J., Smeeding, T., \& Thompson, J. (2016). Inequality and mobility using income, consumption, and wealth for the same individuals. National Poverty Center (NPC) Working Paper Series No. 16-02, Michigan: NPC. Retrieved 04 October 2016 from http://www.npc.umich.edu/publications/u/2016-02-npc-working -paper.pdf

Food and Agriculture Organization [FAO]/World Health Organization [WHO]/United Nations University [UNU] (2001). Human energy requirements. FAO Food and Nutrition Technical Report Series 1. Rome, RM:FAO/WHO/UNU. Retrieved 04 October 2016 from http://www.fao.org/3/a-y5686e.pdf

Forgha, N. G. (2006). An econometric model of poverty in Cameroon: A system estimation approach. International Review of Business Papers, 2(2),30-46.

Gans, H. (1995). The war against the poor. New York, NY: Basic Books.

Gould-Werth, A. (2014). "The help that we get": Racial differences in private safety nets and the scarring effects of unemployment following the great recession. National Poverty Center (NPC) Working Paper Series No. 16-02, Michigan: NPC. Retrieved 04 October 2016 from http://www.npc.umich.edu/publications/u/2014-01-npc-working-paper.pdf

Grusky, B. D. (2001). Social stratification: Race, class and gender. Boulder, Colorado, CLD: Westview Press.

Hurst, C. (2004). Social inequality: Forms, causes and consequences. New York, NY: Pearson Education Inc.

International Monetary Fund [IMF] (2008). Cameroon: Poverty reduction strategy paper progress report. IMF Country, Report No 08/1Washington DC, WDC: IMF. Retrieved 29 March 2016 from https://www.imf.org/external/pubs/ft/scr/2008/cr0801.pdf

James, C. (2006). The place of Lester Ward among sociological classicals, Journal of Classical Sociology, 6(1), 5-21. https://doi.org/10.1177/1468795X06061282

Jung, S. Y., \& Smith, R. (2007). The economics of poverty: Explanatory theories to inform practice, Journal of Human Behavior in the Social Environment, 16(1-2), 21-39. https://doi.org/10.1300/J137v16n01_03

Kouagheu, J. (2015). Cameroun: les 33 ans au pouvoir de Paul Biya laissent les jeunes sans illusion, Le Monde. Retrieved 21 December 2016 from http://www.lemonde.fr/afrique/article/2015/11/05/cameroun-les-33-ans-au-pouvoir-de-paul-biya-laissent-les-jeune s-sans-illusion_4804021_3212.html

LAUREA (n.d). Cameroon country report. Retrieved 21 November 2013 from http://www.laurea.fi/en/connect/results/Documents/Cameroon\%20Country\%20Report.pdf

Lee, S. (2011). Analyzing intra-metropolitan poverty differentiation: Causes and consequences of poverty expansion in suburbs in the Metropolitan Atlanta Region. Annals of Regional Science, 46, 37-57. https://doi.org/10.1007/s00168-009-0324-5

Leveille, J. T. (2015). Rwanda: Paul Kagame vise les 30 ans au pouvoir, LA PRESSE. Retrieved 21 December 2016 from http://www.plus.lapresse.ca/screens/92bad0c3-bcal-458d-aa19-491ffdbf32I-0.html

Lewis, O. (1959). Five families: Mexican case studies in the culture of poverty. New York, NY: Basic Books.

Lichter, D. T., Parisi, D., \& Taquino, M. C. (2011). The geography of exclusion: Race, segregation, and concentrated poverty. National Poverty Center (NPC) Working Paper Series No. 11-16, Michigan: NPC. Retrieved 04 October 2016 from http://www.npc.umich.edu/publications/u/2011-16NPWorkingPaper.pdf

Mateso, M. (2016). Idi Amin Dada: L'ancient tyran se rappelle du bon souvenir des Ougandais, GEOPOLIS. Retrieved 22 December 2016 from http://www.geopolis.francetvinfo.fr/idi-amin-dada-l-ancien-tyran-se-rappelle-au-bon-souvenir-des-ougandais-9645 9

Mead, L. M. (1993). The new politics of poverty:The non working poor in America. New York, NY: Basic Books. 
Meier, G.. M., \& Baldwin, R. E. (1957). Economic development: Theory, history and policy. New York, NY: John Wiley and Sons.

Morrill, R. L., \& Wohlenberg, E. H. (1971). The geography of poverty. New York, NY: McGrawHill.

Mulumbu, G. (2014). Les 10 présidents africains les plus accro au pouvoir, SlateAfrique. Retrieved 01 December 2016 from http: //www.slateafrique.com/432747/les-10-presidents-africains-les-plus-accro-au-pouvoir

Mustapha, A. B., Said, R., \& Sidique, S. (2015). Urban poverty, inequality and industry in Nigeria. International Journal of Development Issues, 14(3), 249-263. https://doi.org/10.1108/IJDI-06-2015-0040

National Institute of Statistics [NIS] (2006). Cameroon statistical yearbook 2006. Yaoundé, YDE: NIS.

NIS (2007). Troisième enquête camerounaise auprès des ménages (ECAMIII): Tendances, profile et déterminants de la pauvreté au Cameroun entre 2001-2007. Yaoundé, YDE: NIS.

Nurkse, R. (1953). Problems of capital formation in underdeveloped countries. Oxford, OXF: Basic Blackwell. Office Central de Promotion Exterieur [OCPE] (2007). Les atouts économiques du Cameroun. Edition 2007. Yaoundé, YDE: OCPE.

Population Reference Bureau [PRB] (2014). 2014 world population sheet.

Quandl (n.d). Cameroon economy data. Retrieved 15 February 2016 from https://www.quandl.com/collections/cameroon/cameroon-economy-data

Quigley, W. P. (2003). Ending poverty as we know it. Philadelphia, PHL: Temple University Press.

Radio AFRICA No 1 (2016). Denis Sassou Nguesso, 32 ans de pouvoir au Congo, prêt pour cinq ans de plus. Retrieved 21 December 2016 from http://www.africa1.com/spip.php?article65622

Radio Okapi (2016). RDC: Joseph Kabila totalise 15 ans au pouvoir. Retrieved 21 December 2016 from http://www.radiookapi.net/2016/01/26/actualite/politique/rdc-joseph-kabila-totalise-15-ans-au-pouvoir

Rank, M. (2004). One nation underprivileged: Why American poverty affects us all. New York, NY: Oxford Press. https://doi.org/10.1093/acprof:oso/9780195101683.001.0001

Rankin, B., \& Quane, J. (2000). Neighborhood poverty and social isolation of inner city African America families. Social Forces, 79(1), 139-164. https://doi.org/10.2307/2675567

Reinstadler, A., \& Ray, J. (2010). Macro determinants of individuall income poverty in 93 regions of Europe. Luxembourg, LMB: European Commission. Retrieved 27 March from http://ec.europa.eu/eurostat/documents/3888793/5846885/KS- RA-10-012-EN.PDF/184ad26b

Republic of Cameroon [RC] (n.d). 3e RGPH-La population du Cameroun en 2010. Retrieved 2 May 2013 from http://www.statistics-cameroon.org/downloads/La_population_du_Cameroun_2010.pdf

Sachs, J. (2005). The end of poverty. London, LND: Penguin.

Sameti, M., Esfahani, R. D., \& Haghighi, H. K. (2012). Theories of poverty: A comparative analysis, Kuwait Chapter of Arabian Journal of Business and Management Review, 1(6), 45-56. Retrieved 15 March 2016 from http://www.omicsonline.com/open-access/theories- of-poverty-a-comparative-analysis-2224-8358-1-151.pdf

Schiller, R. B. (2008). The economics of poverty and discrimination. Upper Saddle River, New Jersey, NJ: Pearson Prentice Hall.

Sen, A. (1999). Development as freedom, Oxford, OXF: Oxford University Press.

Senewebnews-Bitimrew (2012). AFRIQUE: Ces chefs d'état morts au pouvoir. Retrieved 07 December 2016 from http://www.seneweb.com/news/Polirique/afrique-ces-chefs-d=rsque-etat-morts-au-pouvoir_n_57278.html

Shaefer, H. L., Wu, P., \& Edin, K. (2016). Can poverty in America be compared to conditions in the world's poorest countries? National Poverty Center (NPC) Working Paper Series No. 16-07, Michigan: NPC. Retrieved 04 October 2016 from http://www.npc.umich.edu/publications/u/2016-07-npc-working-paper.pdf

Stoll, M. A. (2008). Race, place and poverty revisited. In A. C. Lin \& D. R. Harris (Eds). The colors of poverty: Why racial and ethnic disparities persist. New York, NY: Russell Sage Foundation

Tyrkalov, M. (2015). Lukashenko hits at being president for life as sworn in for fifth term. The Guardian, Friday 6 November 2015. Retrieved 07 December 2016 from

https://www.theguardian.com/world/2015/nov/06/ukashenko-president-for-life-belarus

Ulimwengu, J. M. (2008). Persistent poverty and welfare programs in the United States, IFPRI Discussion Paper 00818.

UN (2010b). Proportion of population using improved sanitation. Retrieved 02 December 2012 from 
http://data.un.org/Data.aspx?q=sanitation+\&d=WHO\&f=MEASURE_CODE\%3aWHSS...

United Nations [UN] (2010a). Proportion of population using improved drinking water sources. Retrieved 02 December 2012 from http://data.un.org/Data.aspx?q=drinking+water\&d=WHO\&f=MEASURE_CODE\%3a...

van Edig, X. F. (2005). Measurement of absolute poverty and indicators of poverty among rural households in central Sulawesi, Indonesia, Diplomaarbeit, Institut für Rurale Entwicklung/Institut für Geographie: Georg-August-Universität, Göttingen, GTN. Retrieved 30 March 2016 from https://ediss.uni-gottingen.de/bitstream/handle/11858/00-1735-0000-000D-F271-E/vanedig.pdf?

Washington DC, WDC: International Food Policy Research Institute (IFPRI). Retrieved 30 March 2016 from https://books.google.cm/books?id=EOTkHlovrOYC\&pg

WB (2013a). Access to electricity (\% of population). Retrieved 2 December 2013 from http://data. worldbank.org/indicator/EG.ELC.ACCS.ZS/countries/1W?display=default

WB (2013b). Inflation, consumer prices (annual \%). Retrieved 10 December 2013 from http://data.worldbank.org/indicator/FP.CPI.TOTL.ZS/countries/1W?display=default

WB (2015). World development indicators database: Gross domestic product 2014. Retrieved 27 July 2015 from http://www.databank. worldbank.org/data/download/GDP.pdf

WB (2016). World development indicators database: Gross domestic product 2014. Retrieved 27 July 2015 from http://www.databank.worldbank.org/data/download/GDP.pdf

Weber, B., \& Jensen, L. (2004). Poverty and place: A critical review of rural poverty literature. Working Paper 04-03, Oregon State University, Oregon, OGN: Rural Poverty Research Center (RPRC).

Weber, M. (2001). Protestant ethic and the spirit of capitalism. New York, NY: Routeledge.

Wilson, W. J. (1996). When work disappears. New York, NY: Viking.

World Bank [WB] (1996). Nigeria: Poverty in the midst of plenty: The challenge of growth with inclusion, AWB Poverty Assessment Report 14733 -UNI, Washington DC, WDC: WB. Retrieved 31 March 2016 from http://www-wds.worldbank.org/serlet/WDSContent/Server/WDSP/IB/1996/05/31/000009265-3961029235646/Re ndered/PDF/multiopage.pdf

World Population Review [WPR] (2015). Country populations 2015. Retrieved 28 July 2015 from http://www.worldpopulationreview.com/countries 


\section{Appendices}

Appendix A.. Pivot table of observed frequencies on respondents'views on economic status type of Cameroon by 2035

\begin{tabular}{lllll}
\hline $\begin{array}{l}\text { Geographical region } \\
\text { Economic status }\end{array}$ & \multicolumn{1}{l}{ Grand North } & Grand West & Grand South & Total \\
\hline Emergence by 2035 & 228 & & & 767 \\
Non-emergence by 2035 & 237 & 328 & 247 & 783 \\
Total & 465 & 620 & 465 & 1550 \\
\hline
\end{tabular}

Appendix B. Pivot table of expected frequencies on respondents'views on economic status type of Cameroon by 2035

\begin{tabular}{llllr}
\hline $\begin{array}{l}\text { Geographical region } \\
\text { Economic status }\end{array}$ & \multicolumn{1}{c}{ Grand North } & Grand West & Grand South & Total \\
\hline Emergence by 2035 & 230.10 & 306.80 & 230.10 & 767 \\
Non-emergence by 2035 & 234.90 & 313.20 & 234.90 & 783 \\
Total & 465 & 620 & 465 & 1550 \\
\hline
\end{tabular}

Appendix C. Chi-square table on respondents' views on economic status type of Cameroon by 2035

\begin{tabular}{llllll}
\hline Economic status & Geographical region & $\mathrm{fo}_{\mathrm{i}}$ & $\mathrm{fe}_{\mathrm{i}}$ & $\mathrm{R}=\left(\mathrm{fo}_{\mathrm{i}}-\mathrm{fe}_{\mathrm{i}}\right)^{2}$ & $\mathrm{X}=\mathrm{R} \div \mathrm{fe}_{\mathrm{i}}$ \\
\hline & Grand North & 228 & 230.10 & 4.41 & 0.0191 \\
Emergence by 2035 & Grand West & 292 & 306.80 & 219.04 & 0.7139 \\
& Grand South & 247 & 230.10 & 285.61 & 1.2412 \\
\hline \multirow{2}{*}{ Non-emergence by 2035 } & Grand North & 237 & 234.90 & 4.41 & 0.0187 \\
- & Grand West & 328 & 313.20 & 219.04 & 0.6993 \\
& Grand South & 218 & 234.90 & 285.61 & 1.2188 \\
\hline
\end{tabular}

\section{Copyrights}

Copyright for this article is retained by the author(s), with first publication rights granted to the journal.

This is an open-access article distributed under the terms and conditions of the Creative Commons Attribution licensewhich permits unrestricted use, distribution, and reproduction in any medium, provided the original work is properly cited. 